\title{
The California Railroad Commission Has Jurisdiction over Intrastate Rates and Charges of Air Lines
}

\author{
Everett C. McKeage*
}

THERE appeared in the March issue of the California Law Review an article by $\mathrm{Mr}$. Theodore E. Wolcott entitled "Does the Jurisdiction of the California Railroad Commission Extend to Air Transportation?"I In this article the writer concluded that the Railroad Commission has no jurisdiction over air transportation companies unless that jurisdiction is specifically provided for by the state legislature, and he further concluded that, at the present time, said Commission has no jurisdiction over air transportation companies under any provision of law. He contends that the term "transportation company" appearing in the constitutional grant of power to the Railroad Commission does not comprehend air transportation companies for the reason that when said term was incorporated in the state constitution air commerce was not in existence or even imagined. With this conclusion I disagree.

The California constitution grants jurisdiction to the Railroad Commission over the rates and charges of all transportation companies and no legislation is necessary to enable the Railroad Commission to exercise that jurisdiction. Briefly, section 20 of Article XII of the state constitution provides that no transportation company shall raise any rate of charge under any circumstances whatsoever except upon a showing before the Railroad Commission that such increase is justified. Also section 21 of that Article provides that a transportation company, upon authorization by the Railroad Commission, may charge less for a longer than for a shorter haul and this section further provides that the Railroad Commission may order any transportation company to make reparation to any shipper on account of excessive rates charged to such shipper. Specifically, in section 22 of said Article of the state constitution we find this provision:

*Chief Counsel, California Railroad Commission.

1 (1945) 33 CaIIF. L. Rev. 114. 
"Said Commission [Railroad Commission] shall have the power to establish rates of charges for the transportation of passengers and freight by railroads and other transportation companies, and no railroad or other transportation company shall charge or demand or collect or receive a greater or less or different compensation for such transportation of passengers or freight, or for any service in connection therewith, between the points named in any tariff of rates, established by said Commission, than the rates, fares and charges which are specified in such tariff. ..." (Emphasis supphed.)

This section goes on to provide that the Commission shall have the further power to examine the books, records and papers of all transportation companies and to hear and determine complaints against transportation companies, etc. Furthermore, this section empowers said Commission and each Commissioner to punish for contempt in the same mamier and to the same extent as courts of record for disobedience of its orders.

It is an elementary rule of constitutional construction that a constitution may be self-executing and even though legislation may be enacted in furtherance of the execution of a constitutional provision, such fact does not detract from the self-executing nature of the constitutional provision, if the language of the constitution is clear on that point. The constitutional provisions immediately above cited are direct grants of jurisdiction and power to the Railroad Commission and do not require any legislation to make them effective, in so far as jurisdiction over rates is concerned. All lawyers are familiar with the construction placed by the United States Supreme Court upon the 13th, 14th and 15th Amendments of the Federal Constitution which is to the effect that, although those amendments provide for legislation to carry out and enforce the provisions of such amendments, nevertheless, such legislation is not necessary in order that the great rights secured by such amendments be availed of by those whom such rights were meant to benefit. Legislation may be enacted that may facilitate the procedure to realize such security but such legislation is not necessary in order that the rights and privileges specifically enumerated in such arnendments be availed of. No claim has ever been made that jurisdiction over transportation companies extends further than the constitutional provision affecting rates, unless and until additional jurisdiction is granted by the legislature as provided in sections 22 and 23 of Article XII of the state constitution. While the writer of the article referred to would have the reader believe that the question under discussion is a highly involved one, the 
exact contrary is true. The state constitution is clear and explicit on this subject and does not require interpretation. It is a familiar rule of construction, particularly with regard to constitutional construction, that plain and unambiguous language must be given its ordinarily accepted meaning and where language is plain and unambiguous, there is no room, in such circumstances, for construction. It is also another familiar rule of constitutional construction that language placed in a constitution by the framers thereof covers and brings within its purview objects that may never have been in the minds of the framers, if the language concerned reasonably covers these objects of control or regulation, which may have come into existence even long after the constitution was framed. For example, all of the great objects and instrumentalities of interstate commerce, such as railroads, motor trucks, airplanes and radio, were not in the minds of the framers of the Federal Constitution; yet the Supreme Court of the United States has never hesitated to hold that the commerce clause of that Constitution covers all new agencies of interstate commence, notwithstanding the fact that the framers of that Constitution could not have remotely imagined the advent of such agencies. The argument made by the writer of this article is on par with the argument made that the commerce clause of the Federal Constitution did not cover air transportation because the framers thereof could not have envisioned such an agency of interstate commerce and therefore the commerce clause could have no application.

The question to be determined in connection with the subject under discussion is whether or not the term "transportation company" includes a company engaged in intrastate air transportation within this state. The Supreme Court of California has held in the case of Western Association of Short Line Railroads v. Railroad Commission ${ }^{2}$ that the term "transportation company" as used in the state constitution mcludes any transportation company operating within the state as a common carrier and not confined exclusively to a municipality or city and county. In that case the question presented was whether or not the Railroad Commission had jurisdiction over a company operating motor busses as a common carrier in this state which operation went outside of a municipality or a city and county, notwithstanding the fact that there was nothing in the way of legislation that directly or indirectly granted such jurisdiction to the Railroad

2 (1916) 173 Cal. 802, 808, 162 Pac. 391, 393, 1 A.L.R. 1455. 
Commission. The Supreme Court of this state held that the constitutional provisions referred to at the outset of this article did give such jurisdiction to the Railroad Commission and that such jurisdiction was a direct grant to that Commission and needed no legislation whatsoever to make such jurisdiction effective, so far as rates were concerned. The supreme court pointed out that the language granting such jurisdiction was clear and that it was the duty of the Railroad Commission to exercise that jurisdiction and, as a matter of fact, issued a writ of mandate to the Commission requiring it to perform its duty. That court experienced no difficulty in holding that the term "transportation company" included within its scope any company operating a transportation service as a common carrier extending beyond the borders of a municipality or a city and county and, that too, notwithstanding the fact that such mode of transportation was not covered by any regulatory legislation or may not have been in existence at the time the constitutional provisions in question were adopted. The writer of the article referred to criticizes this decision of the supreme court of this state but criticisin does not overrule decisions of courts of last resort. The writer attempts to make much of the decision of the supreme court of this state in the case of Railroad Commission v. Market Street Railrevay Company, ${ }^{3}$ which was decided in 1901. It is true that the decision in that case held that the Railroad Commission at that time had no jurisdiction over street railways confined exclusively to a municipality or a city and county. Nothing more was held in that case and in the case of Western Association of Shart Line Railroads v. Railroad Commission, ${ }^{4}$ the supreme court pointed out that fact. It must be realized that in 1911 the state constitution was radically and extensively amended with regard to the powers and the jurisdiction of the Railroad Commission, which showed a clear intent on the part of the people to make of that Commission a vital factor in the governmental scheme of the state. The amendatory provisions themselves show that to be the case, and the history of that particular period conclusively supports this view.

In the article referred to, the writer cites the case of Civic Center Association v. Railroad Commission, ${ }^{5}$ and attempts to draw a conclusion from the decision in that case which is unfavorable or contrary to the decision in the Western Association of Short Line Rail-

\footnotetext{
3 (1901) 132 Cal. 677, 64 Pac. 1065.

4 Supra note 2.

o (1917) 175 Cal. 441, 166 Pac. 351.
} 
roads case. The writer of that article states that in the Civic Center Association case the court decided in favor of muncipal jurisdiction. The exact contrary is true. In that case, the question presented to the supreme court was: Did the City of Los Angeles or the Railroad Commission have jurisdiction to regulate the elevation and depression of steam railroad tracks above and beneath the public streets of Los Angeles? The City of Los Angeles contended that the elevation and depression of railroad tracks above and beneath public streets was a municipal affair and by virtue of the fact that said city existed under a freeholders charter, the jurisdiction of such matters was exclusively in the City of Los Angeles. That being true, said city contended that the Railroad Commission had no jurisdiction. The supreme court decided against the contention of the City of Los Angeles and held that the elevation and depression of steam railroad tracks within that municipality was a matter of general state concern and that the Railroad Commission had jurisdiction. A most superficial reading of the decision in the Civic Center Association case will disclose this to be the holding of the court. As a matter of fact, in this particular case, the court cited approvingly ${ }^{6}$ the case of Western Association of Short Line Railroads. Therefore, it would seem that the reasoning of the writer of the article in question, in so far as the Civic Center Association case is concerned, is not sound. Next, he takes up the case of Frost et al. v. Railroad Commission ${ }^{\tau}$ which was decided by the Califorma supreme court and which was also later considered by the Supreme Court of the United States. ${ }^{8}$ The writer of the article would have the reader believe that the decision by the United States Supreme Court in that case is at variance with the decision in the case of Western Association of Short Line Railroads. The bald fact is that there is nothing in the Frost case which is at variance with the decision in the case of Western Association of Short Line Railroads. All that was held by the United States Suprenie Court in the Frost case was that the State of California did not have the power to require a private contract carrier, as a condition of its continuing to operate upon the public highways of the state, to consent to become a common carrier. The majority decision in that case held that the Auto Stage and Truck Transportation Act of 1917, as the Railroad Commission was attempting to enforce it, amounted to requiring a private carrier

6 Ibid. at $451,166 \mathrm{Pac}$. at 355.

7 (1925) 197 Cal. 230, 240 Pac. 26.

8 Frost Trucking Co. v. Railroad Commission (1926) 271 U.S. 583. 
to transmute itself into a common carrier as a condition to receiving permission to continue to use the public highways of California. $\mathrm{Ob}$ viously, this condition which the State of California was attempting to impose upon a private contract carrier was an unconstitutional requirement, which violated the due process clause of the 14th Amendment of the Federal Constitution. However, it may be said that the two great hiberals of the Supreme Court at that time, Mr. Justice Holmes and Mr. Justice Brandeis, together with Mr. Justice McReynolds, dissented from the majority opinion. Other cases are cited by the writer of the article but only one other requires mention and that is the case In re Martinez. ${ }^{9}$ The only issue involved in that case was whether or not the City of Sacramento had jurisdiction to regulate taxicabs operating exclusively within its corporate limits. Martinez operated a taxicab in violation of a city ordinance and was arrested and convicted. He defended on the ground that the Railroad Commission had exclusive jurisdiction over the operation of taxicabs and, therefore, the ordinance was unconstitutional and void. On habeas corpus, the Supreme Court of Califorma held that Martinez was lawfully convicted of violating a valid ordinance of the City of Sacramento. In so holding, that Court inferentially held that the Railroad Commission did not have jurisdiction over taxicabs operating exclusively within the corporate himits of Sacramento. It is true that the opinion in that case contains dicta which could be construed to mean that the Railroad Commission nuay exercise jurisdiction only where such jurisdiction is given by the legislature. Any such statement in that decision was wholly unnecessary to the deterinination of the issue involved and could not be considered as establishing a rule of law, particularly in the face of a plain and unambiguous provision of the constitution in this state to the contrary.

In the Martinez case the supreme court relied upon a provision of section 23 of Article XII of the state constitution which reads as follows:

"... The railroad commission shall have and exercise such power and jurisdiction to supervise and regulate public utilities, in the State of California, and to fix the rates to be charged for commodities furnished, or services rendered by public utilities as shall be conferred upon it by the Legislature, and the right of the Legislature to confer powers upon the railroad commission respecting public utilities is

9 (1943) 22 Cal. (2d) 259, 138 P. (2d) 10. 
hereby declared to be plenary and to be unlimited by any provision of this constitution."

It must be borne in mind that the grant of jurisdiction to the Railroad Commission over intrastate rates of air transportation companies is found in section 22 of Article XII of the state constitution. Therefore, the provision quoted from section 23 of Article XII can claim no priority over the provision in section 22 unless the former provision is more specific than the latter. As a matter of fact the latter is more specific than the former in so far as the subject to be controlled and regulated is concerned. But we do not have to rely upon this position for the simple reason that section 23 of Article XII contains the following provision:

". . Nothing in this section [Sec. 23 of Art. XII] shall be construed as a limitation upon any power conferred upon the Railroad Commission by any provision of this Constitution now existing or adopted concurrently herewith." (Emphasis supplied.)

Even though it could be said (which is not the case) that anything in section 23 is inconsistent with anything said in section 22 , the provision of section 23 immediately above quoted would give priority to the provisions of section 22 in so far as operative effect and jurisdiction in the Railroad Commission are concerned. Also, section 22 provides in substance that no provision of the state constitution shall be construed as a limitation upon the authority of the legislature to confer upon the Railroad Commission respecting public utilities additional powers of the same kind or different from those conferred by the constitution upon the Commission, which are not inconsistent with the powers conferred upon the Commission by the constitution. It will be noted that section 22 prohibits the legislature from taking away from the Railroad Commission any power which the constitution of the state has conferred upon that Commission. The legislature may confer additional powers upon the Commission but such powers must not be inconsistent with the powers already conferred upon the Commission by the constitution.

It is well to point out that the writer of the article referred to, by inference, would lead the reader to believe that the Railroad Commission asserts that it has all-inclusive jurisdiction over companies engaged in intrastate air transportation. As has been pointed out, this is not true at all. The only jurisdiction which the Railroad Commis- 
sion claims and the only jurisdiction which it has asserted in this regard is jurisdiction over intrastate rates and charges involved in air transportation. As a matter of fact, the Commission has required the filing by air transportation companies of their intrastate rates with the Commission and all such companies have done so, in so far as I an informed. No further or additional jurisdiction has been asserted or the exercise thereof attempted but, as to intrastate rates and charges of air transportation compamies, the Commission does assert and does exercise jurisdiction. 